\title{
Laudatio
}

\section{Cándido Pérez Gallego: Thirty-five years of fruitful scholarship in English Studies}

Enrique Alcaraz Varó.

University of Alicante

\section{Cándido Pérez Gállego, Internet and Textual Harassment}

Somebody once said that, after a dog, the Internet is undeniably a human being's best friend. Nobody is as faithful and obliging as the Internet. It provides you with information that is constantly being updated; it guides you in the search of additional or complementary sources; it even entertains you. Thanks to its ubiquity we can enjoy an endless flow of facts, presented in a most helpful and convenient way. Universities, museums, archives and libraries are digitalizing invaluable manuscripts, historical documents, bibliographies, maps and diagrams, that are ready and waiting to be used. For example, Internet surfers who take the trouble to visit the Acoso Textual web page will be rewarded with a wealth of information from the works of Professor Cándido Pérez Gállego of the Universidad Complutense (Madrid, Spain). However, you do not need to go directly to this web page if you are doing research on Habermas, Freud, Shakespeare, Plato, Silvia Plath, Marcel Proust, Karl Popper and a long list of literary and philosophical greats since most search engines (e.g., Google or Altavista) will provide cross references to 'Textual Harassment', where you will find substantial and thought-provoking ideas and suggestions thrown out by Dr. Pérez Gállego.

The title of this web page, "Textual Harassment", is both modern and tempting. It is modern because the word "harassment" is a witness-word of our modern world: sexual harassment, psychological harassment in the work-place, etc. It is tempting because it entices you to discover what is behind this kind oxymoron called "Textual Harassment". It is an oxymoron since it contains a contradiction in terms; something positive and something negative meet in the same lexical unit, as in the classical example "sweet sorrow". To "harass" is "to torment persistently" and is related to other negative words such as "abuse", "molest" or "mistreat". Unlike "harassment", "textual" is something positive, something that evokes words such as "learning", "scholarship", "research" or even " the pleasure of reading". However, the combination of the two terms in the unit "textual harassment" may have, on a second reading, the positive connotation of somebody being besieged by books and texts whose reading they can't help but read because of the seductiveness of their words.

\section{Cándido Pérez Gallego, a man of books}

Cándido Pérez Gállego is the most prolific writer on English Studies in Spain. I read his first book at the end of the 60s, when my interest in English lexicology drew me to study the vocabulary used by 'the angry young men'. A good friend of mine recommended that I should read Literatura y rebeldía en la Inglaterra actual (Ed. CSIC, Madrid, 1968), where 
she guaranteed that I would find shrewd ideas and penetrating reflections on the values of the society of the fifties. And she was right. Although my interests were more of a linguistic nature, Prof. Pérez Gállego's insights into the language and the style of the English novel of the time were fascinating. Obviously the greatest benefits I reaped from this book related to the language and especially the lexical items which represent reality and, by the same token, the knowledge of the social and literary reality which helped me to understand the vocabulary. The analysis provided in this book, without a doubt, helped me to discover and to organize the lexical units I was then analysing. Such was my first contact with Dr. Pérez Gállego's work.

However, Literatura y rebeldía en la Inglaterra actual was not his first essay. In 1967 he published Notas para una sociologia del teatro isabelino, and before that, in 1966, he had published El héroe solitario en la literatura norteamericana. These three books, which were published within three years of one another, gave us a preview of Dr. Pérez Gállego's virtues and future endeavours. They gave proof of bis literary expertise driven by his clear thinking, his love for quality research and his unflinching will. In addition, they demonstrated his ability to deal with a diverse range of themes within the field of English Studies. In fact, the first text cited deals with modern English drama, the second entails Elizabethan theatre and the third encompasses American literature. These three publications are already clear evidence of the thematic variety and uniqueness which characterizes the broad range of work presented by this outstanding professor of English Studies of the Universidad Complutense.

Juan D. Lasierra, a journalist and writer, said something about Dr. Pérez Gállego which I totally agree with: "Cándido is the most literary person I know. Without literature, I do not think he could exist. His various homes are continuously growing libraries, which eventually drive him out and force him to move to another house". Since he first published Notas para una sociología del teatro isabelino in 1967 , he has had thirty-five years of fruitful scholarship in English Studies which deserve to be recognized by his colleagues, his students and the knowledge community to which he belongs. Recently, he has taken the sensible decision to open a web page, AcosoTextual, which offers a wide range of his works.

\section{Pérez Gállego and Linguistics}

Although Cándido Pérez Gállego is a literary scholar, he also has a notable command of linguistics. In fact, the impression he gives in his writings is that he cannot understand one without the other. His book Sintaxis social (Fundamentos, Madrid) published in 1975, is a profound meditation on linguistics with an abundance of notes and commentaries that reveal his many years of study as a disciple of Noam Chomsky. He organized his Social Syntax into four chapters. The first one elaborates on the linguistic plane based on Chomsky's Language and Mind and conducts a weighty analysis of the relationship between the mind and language. However, his reflections are not based solely on Chomsky's work, but also on the insights of other linguists (Katz, Lakoff, Bolinger, etc.). In the second 
chapter, he deals with the semiotic plane and develops his thought-provoking ideas about macro-syntax, macro-textuality and the macro-system in order to explain narration and communication. In the third chapter, he examines the information plane by pointing towards an external space in which his precision is almost mathematical in quality. The last chapter relates to the social plane, which is interpreted as the context where any sentence loses its ambiguity and becomes an utterance.

The influence that linguistics had upon Pérez Gállego served him for his rhetorical analysis of literary works, literary figures and universal philosophy. This influence is perceived in the titles of his works that contain terms such as: language, syntax, semantics, pragmatics and semiotics. The following are some examples: "Edipo como lenguaje", "Hacia una sintaxis holística de Freud", "Plano sintáctico de la vida cotidiana", "Pliegues sintácticos [Gilles Delleuze]", "Notas semióticas a Albee", "Semántica de la interacción humana", "Pragmática de los actos en Daniel Goleman", "Notas pragmáticas a Levinas", "Notas para la pragmática viajera de Próspero", etc.

\section{Pérez Gállego and Literature}

Literature is obviously second nature to him because he reads, relishes, reflects and then writes about what he has meditated on and taken pleasure in. As a literary scholar he moves from theatre to the novel, to poetry, to essays on the English-speaking world with exceptional ease. He has studied a broad range of Anglo-American literary masters in considerable depth. On Shakespeare he has written Shakespeare y la política (Madrid: Narcea, 1971), Dramática de Shakespeare (Zaragoza, Pórtico, 1974), El testamento de Shakespeare: The Tempest (Valencia: Instituto Shakespeare, 1972), El lenguaje escénico de Shakespeare (Zaragoza: Universidad, 1982). On Henry James we have his Henry James (Madrid: Coloquio, 1987); on James Joyce James Joyce: La revolución de la novela (Madrid: Fundamentos, 1987), etc. The list is incredibly long.

American literature researchers cannot do without Pérez Gállegos's books on the subject. They are more than just worthwhile since they represent many hours of personal reading, reflection and analysis of original versions, as well as a synthesis of the analysis and criticism produced by others on the language, themes (family, competitive society, broken homes and social problems, etc) and style. Amongst his publications are Literatura norteamericana (Barcelona: Planeta, 1977), Literatura norteamericana de hoy (Madrid: Fundamentos, 1977), Guía de la literatura (Madrid: Fundamentos, 1982), La novela norteamericana de los años 80 (Madrid: Fundamentos, 1988), Historia de la literatura norteamericana (Madrid, Taurus, 1988), Literatura norteamericana. Una visión crítica (Madrid, Palas Atenea, 1992). In addition to these personal reflections on American literature, the heroic theme appears to be amongst Dr. Pérez Gállego's favourites. He first studied this theme in the novel El héroe solitario en la novela norteamericana, Madrid, Prensa Española, 1966 and twenty years later in drama El héroe del teatro norteamericano actual, Madrid, Cuadernos Hispanoamericanos, 1987. 


\section{Pérez Gállego and Literary Theory}

Besides his incredible passion for books, Pérez Gállego is also known for his fondness for theorising about literature. His innovative capacity for literary theory-building can be perceived in the personal touch he has put into the titles of his books with theoretical reflections. Some notable examples are Morfonovelística (Madrid: Fundamentos, 1973), Círculos narrativos (Zaragoza, Universidad, 1975), Hamletología (Zaragoza, Universidad, 1975) and Psicosemiótica (Zaragoza, Universidad, 1981). As I have already mentioned, the term 'syntax' is of the utmost importance to him. Everything is brought to order or organized, as can be appreciated in his Sintaxis Social.

He applies this term to an article on literary theory that he published in 1976 "Sintáctica del proceso narrativo" (págs. 431-455 en Teoria de la novela, Madrid, SGEL). Nevertheless, in this case he deals with 'syntactics' and not 'syntax'. 'Syntactics' is a term coined by Morris in his semiotics of signs ("Foundations of the Theory of Signs." International Encyclopedia of Unified Science, vol. 1,2. Chicago: University Press), where he distinguishes three disciplines in the study of language: Pragmatics (the study of signs and their users), Semantics (the study of the relation between signs and the world) and Syntactics (the study of signs in relation to one another). As Pérez Gállego has a deep insight into these disciplines, he studies not only the syntax, but also the vocabulary.

\footnotetext{
"Ambos están rodeados de un vocabulario, sus fronteras son palabras, les acompaña el batir de un mecanismo en el que se abren paso por medio de sus frases que actúan como cuñas encajadas en el "bloque narrado [... . . Cada uno en su orden, cada situación con sus parámetros característicos" (pág. 445).
}

El diálogo en la novela (Nexos, Ediciones Península, Barcelona, 1988) is a pool of ideas organized into eight stimulating chapters: the argument, literature and society, the semiotics of dialogue, the area of conversation, the sociology of literature and pragmatics, the surrounding text, the novel as a semiotic system and the pages of the subconscious. The chapter that struck my attention most is chapter 6 , "the surrounding text", which starts off with a simple yet profound idea: "A novel develops by joining sentences. The relationship between the hero and the others 'appears' to be a pattern of questions and answers". Anyone who reads these chapters carefully will be compensated not only with having learned new things, but also with discovering new ways of reading narratives, which will help them in the future.

\section{Articles and Essays by Pérez Gállego}

Although Pérez Gállego's articles and short essays are not as well known as his book-length studies, they are no less important. Some deal with research, while others are on popular subjects. As a university professor he is well able to write for a general public as well as for his knowledge community. The list of his articles and essays is quite extensive, so here I will only cite a few of the more recent ones: "El pensamiento crítico y filosófico en la 
Universidad de Harvard" (1995), "Temática teatral" (1997), "El partido político de Hamlet" (1999), "La lección del maestro" (1999), "Genética y lingüística" (2002), "David Riesman" (2002), "Hamlet habla de Hamlet" (2002), etc.

\section{The apothegms of Pérez Gállego}

Finally, we must not forget his apothegms. Cándido Pérez Gállego is, above all, a refined intellectual inclined to abstract thinking about aesthetic or philosophical subjects. His methodical, penetrating and disciplined mind is forever thinking, speculating, and conjecturing on any aesthetic or philosophical issue he comes across. For this reason, one cannot help but be attracted to his observations and meditations on philosophers such as Wittgenstein (1996), Habermas or Derrida (1998). These reflections set themselves the difficult task of selecting the author's leading and most original thoughts or in providing meaningful comments on the readings. The selections, as well as the commentaries, are very personal annotations that he calls Notas or Notas semioticas. These notes are found in the form of short numbered paragraphs, much like a checklist encapsulated in no more than three sentences, which Juan D. Lasierra, who knows Pérez Gallego very well, calls apothegms, since they are brief, profound and original. Until now, only his friends were familiar with them. Whenever you received a letter from him you realized he had just written an apothegm. This encapsulated style that began with the philosophers has been extended to other areas of study. Anyone who clicks on Acoso Textual (Textual Harassment) will find more than 200 apothegms written about classical writers (Aeschylus, Euripides, Plato, Parmenides etc.), European writers (Chekhov, Flaubert, Proust, Cervantes, Calderón de la Barca, Ibsen, Kundera), English literature classics (T.S. Eliot, Shakespeare) and Americans (Faulkner, Ashbery, Bellow, Salinger, Melville, Silvia Plath, Miller) and, above all, philosophers of all ages (Habermas, Wittgenstein, Freud, Heidegger, Popper, Dewey, Deleuze, Derrida, Lacan, Chomsky). The list includes more than 200 titles. We should be grateful to him for publishing them on http://www.uv.es/ fores/AcosoTextual/candido2001.html

\section{Recognition}

This long list of books, articles and apothegms is but a small sample of Pérez Gallego's broad culture and scholarship. This note is a modest token of recognition of his 35 years of fruitful contribution to English Studies in Spain. I would like to close by congratulating very sincerely both Cándido Pérez Gállego and his university, Universidad Complutense, for having him on their staff as a professor who not only has an impressive repertoire of publications, but who has also given courses and lectures in the most prestigious European and American universities, from many of which he has received distinguished honours. 